\title{
Pembinaan 8 Standar Pendidikan SD dengan Menggunakan Metode Sasambo dalam Mempersiapkan Akreditasi Sekolah di Kabupaten Sumbawa Barat Tahun 2018
}

\author{
H Wahiddin, S.Pd, MM \\ email:wahidsamba@yahoo.co.id
}

\begin{abstract}
Abstrak: Latar belakang adanya kebijakan akreditasi sekolah di Indonesia adalah bahwa setiap warga negara berhak memperoleh pendidikan yang bermutu. Untuk dapat menyelenggarakan pendidikan yang bermutu, maka setiap satuan pendidikan harus memenuhi atau melampaui standar yang dilakukan melalui kegiatan akreditasi terhadap kelayakan setiap satuan pendidikan. Secara konsep, tujuan diselenggarakannya akreditasi sekolah/madrasah ialah: a). memberikan informasi tentang kelayakan sekolah/madrasah berdasarkan Standar Nasional Pendidikan; b). memberikan pengakuan peringkat kelayakan; dan c). Memberikan rekomendasi tentang penjaminan mutu pendidikan kepada satuan pendidikan yang diakreditasi maupun pihak terkait (BAN-S/ M,2019:6).

Istilah Sasambo untuk singkatan dari Seratus Sembilan Belas Map Bukti Otentik. Sejumlah map yang disiapkan oleh sekolah sebagai tempat menyimpan dokumen bukti administrati 119 indikator penilaian dalam akreditasi sekolah sesuai Permendikbud No 002/ H/ AK/ 2017.

Pembinaan sekolah dengan menggunakan Metode Sasambo sangat efektif dalam pembinaan delapan standar pendidkan untuk menghadapi akreditasi sekolah. Metode ini selain menertibkan administrasi sekolah juga bermanfaat untuk hal-hal sebagai berikut: 1)Metode sasambo memudahkan kepala sekolah dalam mendelegasikan tugas administrasi kepada guru dan stap kependidikan; 2)Tercipta suasana gotong royong dan kerja sama diantara warga sekolah. 3)Semua guru dan stap kependidikan akan memiliki pengalaman yang sama dalam hal administrasi pendidikan yang berhubungan dengan 8 standar. 4)Mempermudah tim penilai akreditasi sekolah dalam memperoleh data tentang kwalitas sekolah secara otentik. 5) Mempercepat waktu penilaian karena semua data sudah tersedia
\end{abstract}

Kata Kunci: Metode Sasambo, Pembinaan, Akreditasi Sekolah, Pengawas Sekolah. 


\section{Pendahuluan}

Dalam usaha peningkatan mutu pendidikan nasional oleh pemerintah selalu dilakukan secara bertahap, terencana dan terukur. Salah satu dasar hukum tentang hal tersebut sebagaiman tertuang dalam Undang-undang Nomor 20 Tahun 2003 tentang Sistem Pendidikan Nasional, BAB XVI Bagian Kedua Pasal 60 tentang Akreditasi.

Latar belakang adanya kebijakan akreditasi sekolah di Indonesia adalah bahwa setiap warga negara berhak memperoleh pendidikan yang bermutu.Untuk dapat menyelenggarakan pendidikan yang bermutu, mak setiap satuan pendidikan harus memenuhi atau melampaui standar yang dilakukan melalui kegiatan akreditasi terhadap kelayakan setiap satuan/ program pendidikan. Adapun delapan standar yang dimaksud adalah: 1) Standar isi; 2) Standar Proses: 3) Standar Kompetensi Lulusan; 4) Standar Kompetensi Pendidik dan Tanaga Kependidikan; 5) Standar Sarana dan Prasarana; 6) Standar Pengelolaan;

Secara konsep, tujuan diselenggarakannya akredirasi sekolah/madrasah ialah: (1) Memberikan informasi tentang kelayakan tentang sekolah/madrasah berdasarkan Standar Nasional Pendidikan; (2) Memberikan pengakuan peringkat kelayakan; (3) Memberikan rekomendasi tentang penjaminan mutu pendidika kepada satuan pendidikan yang diakreditasi dan pihak terkait (BAN-S/ M,2019:6)

Faktanya, penyelenggaraan akreditasi sekolah/madrasah saat ini menghadapi beberapa persoalan, diantaranya: (1) Hasil akreditasi belum menggambarkan hasil obyektif sekolah; (2) Hasil akreditasi belum menunjukkan indicator akuntabilitas; (3) Hasil akreditasi sekolah belum dijadikan alat pembinaan, pengembangan, dan peningkatan mutu pendidikan di sekolah; (4) Peringkat hasil akreditasi belum mampu menggambarkan kelayakan sekolah; dan (5) Hasil akreditasi belum mampu memberikan rekomendasi tentang penjaminan mutu pendidikan.

Pengawas sekolah sebagai salah satu pilar penjamin mutu pendidikan bertanggung jawab dalam membina dan membantu sekolah dalam pemenuhan dan pengembangan depan standar pendidikan sesuai harapan BSNP. Sejauh ini belum kita mendapatkan informasi yang spesifik bagaimana formulasi atau teknik yang tepat dalam pembianaan delapan standar terutama membantu sekolah mempersiapkan diri dalam menghadapi penilaian akreditasi sekolah.

Menurut Pengamatan serta pengamatan penulis sebagai pengawas, tantangan dan hambatan yang sangat sering muncul dalam proses penilaian yaitu, tidak efektifnya waktu yang digunakan selama proses penilaian. Selain itu, pembagian standar yang masih terlihat membingungkan pihak sekolah dalam penyiapan bukti-bukti fisik penilaian. Selama proses penilaian, pihak sekolah, masih kesulitan menyiapkan bukti otentik dari 8 standar yang dinilai yang telah dipecah menjadi lebih dari 130-an bagian. Sehingga melihat pemasalhan ini, penulis bermaksud menyederhanakan dan mengelompokkan ulan bukti otentik tersebut menjadi Seratus Sembilan Belas Map Bukti Otentik (SASAMBO) untuk memudahkan pihak sekolah dalam menyiapkan dan mengefektifkan waktu penilaian oleh pihak penilai. 


\section{A. Rumusan Permasalahan}

Berdasarkan latar belakang permasalahan di atas maka rumusan masalah dalam karya tulis ini adalah:

1. Bagaimanakah model SASAMBO dalam pembinaan delapan standar untuk mempersiapkan sekolah menghadapi penilaian akreditasi sekolah di Sumbawa Barat?

2. Bagaimanakah respon pihak sekolah terhadap kefektifan model SASAMBO dalam persiapan menghadapi penilaian akreditasi sekolah di Sumbawa Barat?

\section{B. Tujuan}

Sejalan dengan apa yang ditelah diuraikan pada bagian terdahulu maka tujuan dari penulisan best practice ini adalah:

1. Mendeskripsikan bagaimana model SASAMBO dalam pembinaan delapan standar untuk mempersiapkan sekolah menghadapi penilaian akreditasi sekolah di Sumbawa Barat.

2. Mengetahui Bagaimana respon pihak sekolah terhadap kefektifan model SASAMBO dalam persiapan menghadapi penilaian akreditasi sekolah di Sumbawa Barat.

\section{Menfaat Penelitian}

Berdasarkan tujuan penulisan karya inovatif Strategi metode SASAMBO dalam pembinaan delapan standar untuk mempersiapkan sekolah menghadapi penilaian akreditasi sekolah di Sumbawa Barat, maka manfaat metode SASAMBO diantaraya yaitu:

1. Bagi Kepala Sekolah

Memudahkan kepala sekolah dalam menyiapkan, serta mengembangkan kinerja kepala sekolah dalam merancang program pengembangan delapan standar pendidikan

2. Bagi Guru

Memudahkan serta menambah wawasan guru dalam pengadministrasian semua kegiatan dari perencanaan sampai pelaporan.

3. Tenaga Kependidikan umumnya

Memudahkan dan mengembangkan kinerja tenaga kependidikan lainnya pada umumnya dalam bersinergi dengan guru dan kepala sekolah.

4. Bagi Masyarakat

Meningkatkan peran masyarakat dalam ikut serta pemenuhan standar pelayanan minimal sekolah.

\section{Pembahasan}

\section{A. Kondisi Ideal}

1. Kondisi Ideal Pendidikan Dasar Menurut SPM

Untuk menjamin tercapainya mutu pendidikan yang diselenggarakan daerah, pemerintah melalui Menteri Pendidikan Nasional telah menetapkan Standar Pelayanan Minimal Pendidikan Dasar, yang dituangkan dalam Peraturan Menteri Pendidikan Nasional No. 15 Tahun 2010. Standar 
pelayanan minimal pendidikan dasar (SPM) merupakan tolok ukur kinerja pelayanan pendidikan dasar, sekaligus sebagai acuan dalam perencanaan program dan penganggaran pencapaian target masing-masing daerah kabupaten/ kota.

Untuk menjamin tercapainya mutu pendidikan yang diselenggarakan daerah, pemerintah melalui Menteri Pendidikan Nasional telah menetapkan Standar Pelayanan Minimal Pendidikan Dasar, yang dituangkan dalam Peraturan Menteri Pendidikan Nasional No. 15 Tahun 2010.

Penyelenggaraan pelayanan pendidikan dasar di dalamnya mencakup; (a) Pelayanan pendidikan dasar oleh kabupaten/kota dan; (b) Pelayanan pendidikan dasar oleh satuan pendidikan.

Pelayanan Pendidikan Dasar oleh Kabupaten/ Kota:

1) Tersedia satuan pendidikan dalam jarak yang terjangkau dengan berjalan kaki yaitu maksimal $3 \mathrm{~km}$ untuk SD/ MI dan $6 \mathrm{~km}$ untuk SMP/MTs dari kelompok permukiman permanen di daerah terpencil;

2) Jumlah peserta didik dalam setiap rombongan belajar untuk SD/MI tidak melebihi 32 orang, dan untuk SMP/MTs tidak melebihi 36 orang. Untuk setiap rombongan belajar tersedia 1 (satu) ruang kelas yang dilengkapi dengan meja dan kursi yang cukup untuk peserta didik dan guru, serta papan tulis;

3) Di setiap SMP dan MTs tersedia ruang laboratorium IPA yang dilengkapi dengan meja dan kursi yang cukup untuk 36 peserta didik dan minimal satu set peralatan praktek IPA untuk demonstrasi dan eksperimen peserta didik;

4) Di setiap SD/MI dan SMP/MTs tersedia satu ruang guru yang dilengkapi dengan meja dan kursi untuk setiap orang guru, kepala sekolah dan staf kependidikan lainnya; dan di setiap SMP/MTs tersedia ruang kepala sekolah yang terpisah dari ruang guru.

5) Di setiap SD/ MI tersedia 1 (satu) orang guru untuk setiap 32 peserta didik dan 6 (enam) orang guru untuk setiap satuan pendidikan, dan untuk daerah khusus 4 (empat) orang guru setiap satuan pendidikan;

6) Di setiap SMP/ MTs tersedia 1 (satu) orang guru untuk setiap mata pelajaran, dan untuk daerah khusus tersedia satu orang guru untuk setiap rumpun mata pelajaran;

7) Di setiap SD/MI tersedia 2 (dua) orang guru yang memenuhi kualifikasi akademik S1 atau D-IV dan 2 (dua) orang guru yang telah memiliki sertifikat pendidik;

8) Di setiap SMP/ MTs tersedia guru dengan kualifikasi akademik S-1 atau D-IV sebanyak 70\% dan separuh diantaranya (35\% dari keseluruhan guru) telah memiliki sertifikat pendidik, untuk daerah khusus masing-masing sebanyak 40\% dan 20\%;

9) Di setiap SMP/ MTs tersedia guru dengan kualifikasi akademik S-1 atau D-IV dan telah memiliki sertifikat pendidik masing-masing satu orang untuk mata pelajaran Matematika, IPA, Bahasa Indonesia, dan Bahasa Inggris; 
10) Di setiap Kabupaten/Kota semua kepala SD/MI berkualifikasi akademik S-1 atau D-IV dan telah memiliki sertifikat pendidik;

11) Di setiap kabupaten/kota semua kepala SMP/MTs berkualifikasi akademik S-1 atau D-IV dan telah memiliki sertifikat pendidik;

12) Di setiap kabupaten/kota semua pengawas sekolah dan madrasah memiliki kualifikasi akademik S-1 atau D-IV dan telah memiliki sertifikat pendidik;

13) Pemerintah kabupaten/kota memiliki rencana dan melaksanakan kegiatan untuk membantu satuan pendidikan dalam mengembangkan kurikulum dan proses pembelajaran yang efektif; dan

14) Kunjungan pengawas ke satuan pendidikan dilakukan satu kali setiap bulan dan setiap kunjungan dilakukan selama 3 jam untuk melakukan supervisi dan pembinaan.

Pelayanan Pendidikan Dasar oleh Satuan Pendidikan:

1) Setiap SD/MI menyediakan buku teks yang sudah ditetapkan kelayakannya oleh Pemerintah mencakup mata pelajaran Bahasa Indonesia, Matematika, IPA, dan IPS dengan perbandingan satu set untuk setiap peserta didik;

2) Setiap SMP/MTs menyediakan buku teks yang sudah ditetapkan kelayakannya oleh Pemerintah mencakup semua mata pelajaran dengan perbandingan satu set untuk setiap perserta didik;

3) Setiap SD/MI menyediakan satu set peraga IPA dan bahan yang terdiri dari model kerangka manusia, model tubuh manusia, bola dunia (globe), contoh peralatan optik, kit IPA untuk eksperimen dasar, dan poster/ carta IPA;

4) Setiap SD/MI memiliki 100 judul buku pengayaan dan 10 buku referensi, dan setiap SMP/ MTs memiliki 200 judul buku pengayaan dan 20 buku referensi;

5) Setiap guru tetap bekerja 37,5 jam per minggu di satuan pendidikan, termasuk merencanakan pembelajaran, melaksanakan pembelajaran, menilai hasil pembelajaran, membimbing atau melatih peserta didik, dan melaksanakan tugas tambahan;

6) Satuan pendidikan menyelenggarakan proses pembelajaran selama 34 minggu per tahun dengan kegiatan tatap muka sebagai berikut :

(a) Kelas I - II : 18 jam per minggu; (b) Kelas III : 24 jam per minggu;

(c) Kelas IV - VI : 27 jam per minggu; atau (d) Kelas VII - IX : 27 jam per minggu;

7) Satuan pendidikan menerapkan kurikulum tingkat satuan pendidikan (KTSP) sesuai ketentuan yang berlaku;

8) Setiap guru menerapkan rencana pelaksanaan pembelajaran (RPP) yang disusun berdasarkan silabus untuk setiap mata pelajaran yang diampunya;

9) Setiap guru mengembangkan dan menerapkan program penilaian untuk membantu meningkatkan kemampuan belajar peserta didik;

10) Kepala sekolah melakukan supervisi kelas dan memberikan umpan balik kepada guru dua kali dalam setiap semester; 
11) Setiap guru menyampaikan laporan hasil evaluasi mata pelajaran serta hasil penilaian setiap peserta didik kepada kepala sekolah pada akhir semester dalam bentuk laporan hasil prestasi belajar peserta didik;

12) Kepala sekolah atau madrasah menyampaikan laporan hasil ulangan akhir semester (UAS) dan Ulangan Kenaikan Kelas (UKK) serta ujian akhir (US/ UN) kepada orang tua peserta didik dan menyampaikan rekapitulasinya kepada Dinas Pendidikan Kabupaten/Kota atau Kantor Kementerian Agama di kabupaten/kota pada setiap akhir semester; dan

13) Setiap satuan pendidikan menerapkan prinsip-prinsip manajemen berbasis sekolah (MBS).

\section{Kondisi Ideal Menurut Tagihan Akreditasi Sekolah}

Lingkup standar nasional pendidikan terdapat dalam Peraturan Pemerintah No 19 Tahun 2005 tentang standar pelayanan pendidikan serta beberapa indikaror untuk mengukur ketercapaian delapan standar tersebut seperti yang tertuang dalam Permendikbud Nomor 002/H/ AK/ 2017 sebagai berikut:

\section{a. Standar isi}

Standar isi adalah ruang lingkup materi dan tingkat kompetensi yang dituangkan dalam kriteria tentang kompetensi tamatan, kompetensi bahan kajian, kompetensi mata pelajaran, dan silabus pembelajaran yang harus dipenuhi oleh peserta didik pada jenjang dan jenis pendidikan tertentu.

Ada 10 indikator pemenuhan adalah sebagai berikut:

1) Semua guru mengembangkan perankat pembelajaran pada sikap spiritual siswa

2) Semua guru mengembangkan perankat pembelajaran pada sikap social siswa

3) Semua guru mengembangkan perankat pembelajaran pada sikap pengetahuan siswa

4) Semua guru mengembangkan perankat pembelajaran pada sikap keterampilan siswa

5) Sekolah mengembangkan perankat Pendidikan Agama dan Budi Pekerti

6) Sekolah mengembangkan perankat pembelajaran tematik pada setiap kelas

7) Kepala sekolah dan guru melibatkan: pengawas, narasumber, komite dan penyelengara dalam mengembangkan KTSP

8) Penyusunan KTSP memuat: (a) Visi, misi, tujuan, (b) pengorganisasian muatan kurikuler, (c) pengaturan beban mengajar/ belajar, (d) kalender pendidikan, (e) silabus, (RPP)

9) Penyusunan KTSP melalui tahapan: (a) analisis, (b)penyusunan, (c) penetapan, (pengesahan)

10) Melaksanakan kurikulum yang memuat 5 ketentuan: (a) Berstruktur, (b) Kegiantan mandiri maksimal 40\%, (c) Beban belajar dan 
mengajar sesuai ketentuan, (d) Ada mata pelajaran seni dan prakarya, (e) Pengembangan diri

\section{b. Standar proses;}

Standar proses adalah standar nasional pendidikan yang berkaitan dengan pelaksanaan pembelajaran pada satu satuan pendidikan untuk mencapai standar kompetensi lulusan, yaitu meliputi:

1) Sekolah mengembangkan silabus yang membuat komponen: identitas mata pelajaran/tema, identitas sekolah, KI, KD, materi pokok, kegiatan pembelajaran, penilaian, alokasi waktu, dan sumber belajar.

2) Semua guru mengembangkan RPP dan silabus secara lengkap dan sistimatis.

3) Sekolah mengalokasikan waktu dan beban belajar sesuai ketentuan: durasi 1 jam pembelajaran, beban belajar per minggu, beban belajar per semester, dan beban belajar pertahu pelajaran.

4) Jumlah siswa per rombongan belajar 28 orang.

5) $100 \%$ siswa menggunakan buku teks sesuai ketentuan.

6) Guru melakukan pengelolaan kelas yang benar (12 kreteria)

7) Semua guru membuka pelajaran dengan baik,

8) Semua guru menggunakan model pembelajaran yang sesuai karakteristik siswa

9) Semua guru menggunakan metode pembelajaran yang sesuai karakteristik siswa dan mata pelajaran

10) Semua guru menggunakan media pembelajaran yang sesuai karakteristik siswa

11) Semua guru menggunakan sumber belajaryang sesuai karakteristik siswa dan tema

12) Semua guru menggunakan pendekatan pembelajaran yang sesuai karakteristik siswa

13) Semua guru menutup pelajaran dengan menggunakan langkahlangkah yang baik

14) Semua guru menggunakan penilaian otentik dalam penilaian proses pembelajaran

15) Guru memanfaatkan hasil penilaian utuk merencanakan: remedial, pengayaan, pelayanan konsling, dan perbaikan

16) Kepala sekolah melakukan pengawasan proses pembelajaran dengan obyektif dan transparan guna meningkatkan mutu secara berkelanjutan

17) Kepala sekolah melakukan supervisi proses pembelajaran terhadap seluruh guru

18) Kepala sekolah memantau proses pembelajaran melalui diskusi kelompok terfokus, pengamatan, pencatatan, perekaman, wawancara, dan pendokumentasian

19) Kepala sekolah menindaklanjuti hasil supervise proses pembelajaran dengan cara: pemberian contoh, diskusi, konsultasi, dan pelatihan

20) Kepala sekolah menyusun: laporan pemantauan, laporan supervisi, laporan evaluasi proses pembelajaran, dan program tindak lanjut 
21) Kepala sekolah menindaklanjuti hasil pengawasan minimal 1 tahun terakhir

\section{c. Standar kompetensi lulusan;}

Standar kompetensi lulusan adalah kualifikasi kemampuan lulusan yang mencakup sikap, pengetahuan, dan keterampilan dengan idikator sebagai berikut

1) Siswa memiliki perilaku yang mencerminkan sikap bercermin dan bertakwa kepada Tuhan YME, sesuai dengan perkembangan siswa yang diperoleh dari sumber belajar melalui (9 kegiatan pembiasaan).

2) Siswa mencerminkan prilaku yang mencerminkan sikap social dengan karakter: jujur dan bertanggung jawab, peduli, gotong-royong dan demokratis, percaya diri, dan nasionalisme yang diperoleh melalui kegiatan pembelajaran dan pembiasaan.

3) Siswa memiliki perilaku yang mencerminkan sikap pembelajaran sejati sepanjang hayat sesuai dengan perkembangan anak, yang diperoleh dari pengalaman pembelajaran dan pembiasaan melalui kegiatan literasi (6 kegiatan).

4) Siswa memiliki prilaku yang mencerminkan sikap sehat jasmani dan rohani melalui keterlibatan dalam kegiatan kesiswaan, berupa: olahraga, seni, kepramukaan, UKS, keagamaan, dan lomba yang terkait.

5) Siswa memiliki pengetahuan: faktual, konseptual, prosedural, metakognitif dalam setiap tema sesuai dengan pembelajaran tematik terpadu.

6) Siswa memiliki pengalaman belajar yang ditunjukkan oleh kemampuan untuk melakukan kegiatan seni dan budaya lokal (minimal 5 kegiatan)

7) Siswa memperoleh pengalaman belajar menggunakan informasi tentang lingkungan sekitar secara logis, kritis, dan kreatif melalui pemanfaatan sumber belajar berupa: bahan ajar, buku teks, perpustakaan, alat praga, dan internet.

\section{d. Standar pendidik dan tenaga kependidikan;}

Standar pendidik dan tenaga kependidikan adalah kriteria pendidikan prajabatan dan kelayakan fisik maupun mental, serta pendidikan dalam jabatan.

Indikatornya adalah sebagai berikut:

1) Semua guru memiliki kualifikasi akademis $S 1$

2) Semua guru memiliki sertifikat pendidik

3) Guru mengajar sesuai dengan latar belakang pendidikan atau uji kelayakan

4) Semua guru mata pelajaran mengajar sesuai dengan latar belakang pendidikannya

5) Semua guru memiliki kompetensi paedagogik

6) Semua guru memiliki kompetensi professional

7) Semua guru memiliki kompetensi kepribadian

8) Semua guru memiliki kompetensi sosial 
9) Semua guru melaksanakan tugas layanan konsling yang meliputi kompetansi professional

10)Kepala sekolah memiliki persyaratan sesuai Permendiknas No 13 tahun 20017

11)Kepala sekolah memiliki kompetensi manajerial

12)Kepala sekolah memiliki kemampuan kewirausahaan

13)Kepala sekolah memiliki kemampuan supervise proses pembelajaran

14)Sekolah memiliki tenaga administrasi yang cukup dan sesuai bidang tugas dengan latar belakang pendidikannya

15)Memiliki tenaga perpustakaan yang cukup dan berkompeten

16)Sekolah memiliki petugas layanan khusus minimal 4 orang

\section{e. Standar sarana dan prasarana;}

Standar sarana dan prasarana adalah standar nasional pendidikan yang berkaitan dengan kriteria minimal tentang ruang belajar, tempat berolahraga, tempat beribadah, perpustakaan, laboratorium, bengkel kerja, tempat bermain, tempat berkreasi dan berekreasi, serta sumber belajar lain, yang diperlukan untuk menunjang proses pembelajaran, termasuk penggunaan teknologi informasi dan komunikasi.

Indikator standar sarana dan prasarana adalah:

1) Sekolah memiliki luas lahan sesuai dengan ketentuan luas minimal

2) Lahan sekolah memenuhi ketentuan; (a) Terhindar dari potensi bahaya yang mengancam kesehatan dan keselamatan jiwa, (b) Memiliki asks untuk penyelamatan darurat, (c) Terhindar dari pencemaran air, (d) Terhindar dari kebisingan, dan (e) Terhindar dari pencemaran udara.

3) Sekolah memiliki luas lantai sesuai dengan ketentuan

4) Bangunan sekolah memiliki persyaratan keselamatan meliputi: (1a) Konstruksi yang stabil, (b) Konstruksi yang kokoh, (c) System pencegahan dari bahaya kebakaran, (d) Fasilitas ramah anak, dan (e) Penangkal petir.

5) Bangunan sekolah memenuhi persyaratan kesehatan: vetilasi, pencahayaan, sanitasi, tempat sampah, dan bahan bangunan yang aman.

6) Bangunan sekolah memiliki instalasi listrik dengan daya mencukupi kebutuhan (2200 watt).

7) Sekolah melakukan pemeliharaan berkala minimal 5 tahun sekali.

8) Sekolah memiliki prasarana yang lengkap sesuai dengan ketentuan dengan kondisi baik.

9) Sekolah memiliki ruang kelas dengan jumlah dan ukuran sesuai dengan ketentuan.

10)Sekolah memiliki perpustakaan dengan luas dan perlengkapan sesuai ketentuan.

11)Sekolah memiliki alat praga pempelajaran yang lengkap.

12)Sekolah memiliki ruang kepala sekolah yang khusus sesuai ukuran dan kelengkapan sesuai dengan ketentuan.

13)Sekolah memiliki ruang guru dengan rasio minimum $4 \mathrm{~m}$ persegi/ guru dengan prabot dan kelengkapan yang lengkap. 
14)Sekolah memiliki tempat ibadah bagi warga sekolah dengan luassesuai ketentuan dan kelengkapan yang lengkap.

15)Sekolah memiliki ruang UKS dengan ukuran dan kelengpan yang sesuai dan lengkap.

16)Sekolah memiliki jamban dengan ketentuan jumlah jumlah yang cukup, higinis, cukup air, dan sarana yang lengkap.

17)Sekolah meiliki gudang yang baik.

18)Sekolah memiliki tempat bermain, olahraga, berkesenian, keterampilan, dan upacara yang layak.

19)Sekolah memilki ruang sirkulasi yang memenuhi ketentuan: luas, berkualitas, terawatt, dan nyaman.

20)Sekolah memilki kantin yang higinis serta makanan yang sehat.

21)Sekolah memiliki tempat parker yang cukup sesuai ketentuan.

\section{f. Standar pengelolaan}

Standar pengelolaan adalah standar nasional pendidikan yang berkaitan dengan perencanaan, pelaksanaan, dan pengawasan kegiatan pendidikan pada tingkat satuan pendidikan, kabupaten/kota, provinsi, atau nasional agar tercapai efisiensi dan efektivitas penyelenggaraan pendidikan.

Indikator untuk standar pengelolaan adalah:

1) Sekolah memiliki visi, misi, dan tujuan yang telah melalui proses: perumusan, keputusan, penetapan, peninjauan

2) Sekolah merumuskan dan menetapkan RKJM dan RKT sesuai ketentuan.

3) Sekolah memiliki sembilan dokumen pedoman pengelolaan

4) Sekolah memiliki struktur organisasi yang lengkap dan efektif.

5) Sekolah melaksanakan 100\% kegiatan sesuai rencana kerja tahunan,

6) Sekolah melaksanakan kegiatan kesiswaan yang meliputi PPDB, layanan konseling, ekstra kurikuler, pembinaan prestasi, penelusuran alumni

7) Sekolah melaksanakan pengelolaan kurikulum: KTSP, kalender pendidikan, program pembelajaran, penilaian hasil belajar siswa, dan peraturan akademik.

8) Sekolah mendayagunakan tenaga pendidik dan tenaga kependidikan : pemenuhan kebetuhan, pemberdayaan, promosi, dan penghargaan.

9) Sekolah melaksanakan penilaian kinerja pendidik dan tenaga kependidikan.

10)Sekolah menyusun pedoman pengelolaan pembiayaan investasi dan operasional sesuai ketentuan.

11)Sekolah melibatkan peran serta masyarakat dan membangun kemitraan dengan lembaga lainyang relevan dalam melakukan berbagai kegiatan pengelolaan pendidikan.

12)Sekolah melaksanakan kegiatan evaluasi diri terhadap kinerja sekolah dalam pemenuhan SNP.

13)Kepala sekolah melaksanakan tugas kepemimpinan dengan baik.

14)Kepala sekolah dalam pengelolaan sekolah menerpkan prinsipprinsip kepemimpinan pembelajaran. 
15)Sekolah memiliki Sistem Informasi Manajemen yang baik.

\section{g. Standar pembiayaan}

Standar pembiayaan adalah standar yang mengatur komponen dan besarnya biaya operasi satuan pendidikan yang berlaku selama satu tahun dengan indicator sebagai berikut:

1) Sekolah memiliki RKA tiga tahun yang memuat alokasi anggaran untuk investasi.

2) Sekolah memiliki RKA tiga tahun yang memuat alokasi anggaran untuk biaya operasi nonpersonalia.

3) Sekolah memiliki dokumen investasi sarana dan prasarana secara lengkap.,

4) Sekolah membelanjakan biaya untuk pengembangan pendidik dan tenaga kependidikan berdasarkan RKA secara maksimal.

5) Sekolah merealisasikan modal kerja sebesar yang tertuang dalam RKA.

6) Sekolah menyampaikan biaya operasional untuk guru dan tenaga kependidikan seperti gaji, honor, intensif, dan tunjangan lain.

7) Sekolah merealisasikan rencana belanja anggaran pengadaan ATK sesuai RKA.

8) Sekolah merealisasikan rencana belanja anggaran pengadaan bahan habis pakai untuk pos pembelajaran sesuai RKA.

9) Sekolah merealisasikan rencana belanja anggaran pemeliharaan dan perbaikan berkala sarpras sesuai RKA.

10)Sekolah merealisasikan rencana belanja anggaran daya dan jasa sesuai RKA

11)Sekolah merealisasikan rencana belanja biaya transportasi dan perjalanan dinas serta konsumsi secara maksimal sesuai RKA.

12)Sekolah merealisasikan rencana belanja anggaran untuk kegiatan pembinaan siswa sesuai RKA.

13) Sekolah merealisasikan rencana belanja anggaran untu pelaporan sesuai RKA.

14)Sekolah mengelolah dengan baik sumbangan pendidikan atau dana dari masyarakat.

15)Sekolah memiliki pembukuan keuangan yang lengkap.

16)Sekolah memiliki pelaporan pertanggung jawaban keuangan yang disampaikan kepada yang berkepentingan.

h. Standar penilaian pendidikan.

Standar penilaian pendidikan adalah standar nasional pendidikan yang berkaitan dengan mekanisme, prosedur, dan instrumen penilaian hasil belajar peserta didik dengan indikator sebagai berikut:

1) Guru melaksanakan penilaian hasil belajar dengan prinsip: sahih, objektif, adil, terbuka, holistic, dan akuntabel.

2) Sekolah menentukan KKM seluruh mata pelajaran dengan prosedur analisis yang dipertimbangkan.

3) Guru melaksanakan penilaian hasil belajar dalam bentuk: ulangan, pengamatan, penugasan, dan atau bentuk lain yang diperlukan. 
4) Guru menggunakan hasil penilaian kompetensi pengetahuan untuk: memperbaiki proses, mengukur ketercapaian tujuan, dan pertimbangan kenaikan kelas/ kelulusan.

5) Guru melaksanakan penilaian kompetensi sikap sesuai karakteristik $\mathrm{KD}$.

6) Guru melaksanakan penilaian kompetensi pengetahuan sesuai karakteristik $\mathrm{KD}$

7) Guru melaksanakan penilaian kompetensi keterampilan sesuai karakteristik KD

8) Guru melaksanakan penilaian kompetensi sikap melalui observasi/ pengamatan dan teknik penilaian yang relevan.

9) Guru melaksanakan penilaian kompetensi pengetahuan dengan menggunakan tes tulis, tes lisan, dan penugasan.

10) Guru melaksanakan penilaian kompetensi keterampilan menggunakan: tes praktek, penilaian produk, penilaian proyek, penilaian portofolio dan teknik lain yang sesuai.

11)Sekolah melaksanakan penilaian hasil belajar dalam bentuk: $\mathrm{PH}$, PAS, PAT, dan US,

12)Gekoah menentukan kelulusan siswa dengan mempertimbangkan hasil: ujian sekolah, penilaian sikap, penilaian pengetahuan, dan penilaian keterampilan.

13)Guru melakukan penilaian proses dan hasil belajar dengan 8 langkah: (a) Menetapkan tujuan, (b) Menyusun kisi-kisi, (c) Mengembangkan instrument dan pedoman penilaian, (d) Analisis instrument, (e) Mengolah dan menentukan kelulusan siswa, (f) Melaporkan, (g) Memanfaatkan hasil penilaian.

\section{B. Prosedur Pembinaan}

Adapun prosedur pembinaan dalam menerapkan best practice ini yaitu digambarkan oleh bagai 2.1 berikut.

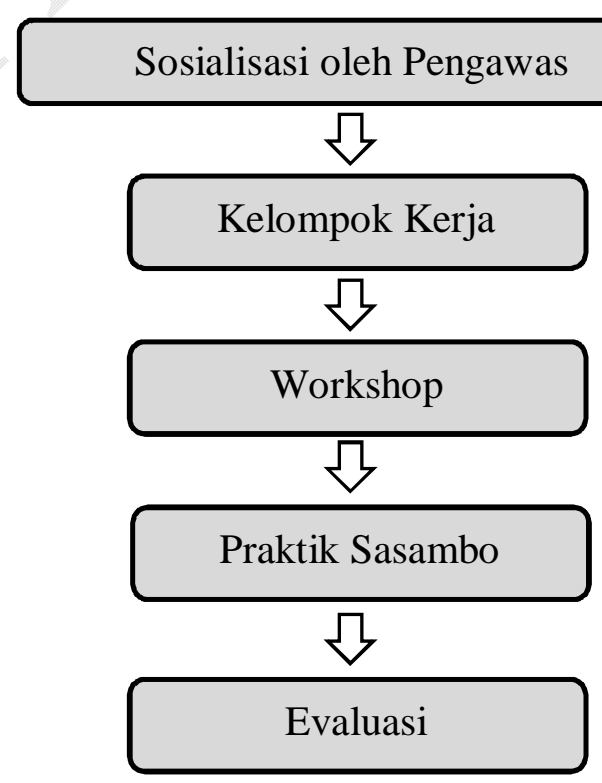


Bagan 2.1. Struktur prosedur pembinaan

Pada proses pembinaan, penulis menyusun dan membuat konsep SASAMBO serta penjelasan secara rinci, jelas dan padat. menyusun tahap selanjutnya yaitu melakukan sosialisasi kepada pengawas serta melakukan komunikasi kepada kepala sekolah dan guru serta tenaga kependidikan lainnya. Kemudian kepala sekolah dan guru membuat penyesuaian program yang diinisiasi oleh pengawas sekolah. Program tersebut akan dibicarakan saat kegiatan sosialisasi.

Setelah proses sosialisasi, maka pembinaan dilanjutkan pada pembentukan kelompok kerja dan penjelasan sistem sasambo melalui workshop dan diskusi terbatas. Pada proses workshop, pihak sekolah diberikan pelatihan metode SASAMBO secara singkat dan jelas. Setelah pihak sekolah memahami metode SASAMBO, maka sekolah akan memulai menerapkan metode SASAMBO ketika menghadapi proses penilaian akreditasi. setelah proses praktik SASAMBO, penulis melakukan evaluasi dengan membagikan angket respon efektifitas Metode SASAMBO kepada guru dan sekolah yang terlibat selama proses penilaian akreditasi sekolah.

\section{Hasil Inovasi}

\section{Metode dan Langkah-Langkah Inovasi}

\section{Metode dan Langkah-langkah Inovasi}

Metode yang penulis gunakan dalam inovasi pembinaan ini adalah metode supervisi manajerial dengan teknik Pembinaan inhouse trainning. Penulis menerapkan cara menyusun program pembinaan dan memantau kegiatan sekolah melalui terpenuhinya Seratus Sembilan belas map bukti otentik beserta instrumen tagihan.

\section{Waktu dan Tempat Pelaksanaan}

\section{a. Tempat}

Pembimbingan karya inovatif ini dilaksanakan pada semua sekolah yang berada di wilayah binaan di Kecamatan Sekongkang dan sekolah-sekolah yang sengaja mengundang sebagai instrutur di wilayah Kabupaten Sumbawa Barat, terutama sekolah yang akan dinilai oleh tim akreditasi sekolah. Alasan pemilihan sekolah binaan adalah untuk membantu sekolah dalam mempersiapkan diri pada proses akreditasi sekolah supaya hasilnya lebih terukur maksimal.

\section{b. Waktu pelaksanaan}

Pembinaan inovatif ini penulis laksanakan pada awal bulan Februari sampai dengan awal bulan Mei 2017.

\section{Inovasi Yang Diterapkan}

Karya inovasi ini oleh penulis istilahkan Metode Sasambo. "Sasambo" adalah kata yang cukup popular di telinga masyarakat Provinsi Nusa Tenggara Barat karena merupakan akronim dari singkatan nama suku yang ada di Provinsi Nusa Tenggara Barat yaitu: Sasak, Samawa, dan Mbojo. Suku Sasak adalah suku asli masyarakat Lombok, suku Samawa adalah suku asli yang mendiami Kabupaten Sumbawa dan Sumbawa Barat, sedangkan Mbojo adalah sebutan nama Suku untuk masyarakat Kabupaten Bima dan Kabupaten Dompu. 
Untuk karya kali ini penulis meminjam istilah Sasambo untuk singkatan dari Seratus Sembilan Belas Map Bukti Otentik. Sejumlah map yang disiapkan oleh sekolah sebagai tempat menyimpan dokumen bukti administrati 119 indikator penilaian dalam akreditasi sekolah sesuai Permendikbud No 002/ H/ AK/ 2017.

Map didesain sedemikian rupa dengan cara:

a. Pemberian nomor urut map untuk mempermudah pencarian dokumen;

b. Menempelkan pertanyaan dan oftions pilihan jawaban di depan map agar penilai dengan cepat mengetahui jawaban hasil EDS.

c. Menempelkan petunjuk teknis di dalam map sebelah kiri dengan maksud agar tidak ada pedebatan antara sekolah dan penilai;

d. Menempelkan salinan bukti pengumpulan data pada bagian map dalam sebelah kanan agar mempermudah pegecekan

Seratus Sembilan Map tersebut akan berisi :

a. Bukti fisik secara utuh: misalnaya photocopy Ijazah guru-guru, photocopy sertifikat tanah, photocopy rekning listerik, dan lainlain.

b. Bukti fisik sebagian: misalnya contoh RPP, contoh silabus, contoh daftar nilai, contoh buku pegangan siswa, dan lain-lain.

c. Petunjuk bukti fisik: seperti denah sekolah, denah ruang, letak bak sampah, dan lain-lain.

d. Penjelasan bukti fisik seperti perhitungan anggaran per item per tahun, keterangan pengaliahn fungsi ruangan, dan lain-lain.

\section{Langkah-langkah Pembinaan}

\section{a. Sosialisasi}

Definisi sosialisasi menurut Robert M.Z. Lawang adalah proses mempelajari norma, nilai, peran, dan semua persyaratan lainnya yang diperlukan untuk memungkinkan berpartisipasi yang efektif dalam kehidupan social. Merujuk definisi tersebut maka pengawas mensosialisalikan tentang Pengadministrasian delapan standar pendidikan dengan menggunakan Metode Sasambo dalam kaitannya dengan persiapan menghadapi akreditasi sekolah. Adapun materi sosialisasi adalah: delapam standar pendidikan, pentingnya akreditasi sekolah, orang-orang yang terlibat dan perannya, dan Metode Sasambo.

\section{b. Pembentukan kelompok kerja}

Kelompok kerja formal dibedakan menjadi dua yaitu kelompok komando (command group) dan kelompok tugas (task group). Dalam hal ini kepala sekolah dibimbing oleh pengawas membentuk kelompok kerja dalam pengertian task group karena berupa kelompok kecil yang berisi 2-3 orang. Kelompok ini beranggotakan antara lain: guru, tenaga kependidikan lainnya, komite/ masyarakat, peserta didik. Setiap kelompok menangani pengadministrasian satu sandar pendidikan. Sesuai dengan sasaran pekerjaan maka kelompok dibedakan menjadi 8 (delapan) kelompok: 
1) kelompok standar Isi; karena banyak membicarakan tentang kurikulum maka anggota kelompok ini sebaiknya dikoordinir oleh unsure team pengemnang kurikulum di sekolah.

2) standar proses; standar proses adalah fokus membicarakan tentang persiapan dan pelaksanaan pembelajaran, maka yang menjdi anggota kelompok ini adalah guru senior atau tutor pelaksanaan K13 atau sejenisnya.

3) standar kompetensi lulusan; anggota standar ini adalah sebaiknya dari unsur Pembina ekstrakurikuler: baik dari pramuka, olahraga, seni, maupun keagamaan.

4) standar tenaga pendidik dan tenaga kependidikan; karena kelompok ini berkaitan dengan sumber daya manusia maka sebaiknya kelompok ini dikordinir langsung oleh kepala sekolah

5) starndar sarana dan prasarana; kelompok kerja yang menangani standar ini sebaiknya dikoordinir oleh bendahara barang karena banyak yang menyangkut inventaris.

6) standar pengelolaan; standar pengelolaan sebainya dilibatkan operator sekolah karena kelompok ini banyak bersesuaian dengan dapodik.

7) standar pembiayaan; kelompok ini dikoordinir oleh bendahara sekolah karena banyak membicarakan masalah program dan menggunaan pembiayaan sekolah.

8) Standar penilaian; kelompok terakhir ini sebaiknya dikoordinir oleh wakil kepala sekolah karena disamping senior, wakil kepala sekolah dianggap banyak memahami tentang penilaian.

\section{c. Workshop identifikasi masalah dan pemecahannya}

Menurut kamus besar bahasa Indonesia, lokakarya (w orkshop): "pertemuan untuk bertukar pengetahuan dan pengalaman diantara sejumlah peserta yang mempunyai keahlian atau profesi yang sama, guna meningkatkan pengetahuan atau memecahkan suatu masalah." Tahap ini semua anggota kelompok kecil diberikan bekal berupa: juknis pengisian instrument, Instrumen akrditasi sekolah, dokumen pengumpulan data, serta aplikasi penskoran nilai. Pengawas sekolah menjelaskan kepada setiap anggota kelompok tentang materi secara umum yang selanjutnya semua anggota kelompok mengidentifikasi masalah dan mendiskusikannya sesama teman sejawat dibawah bimbingan pengawas sekolah.

\section{d. Pelaksanaan/ melengkapi data}

Guru secara kelompok mengiventarisir, mengumpulkan, membuat, dan mengarsipkan data di dalam map yang sesuai. Kegiatan ini dibimbing oleh pengawas sekolah dan kepala sekolah. 


\section{e. Evaluasi}

Tahap ini sekolah mengadakan simulasi penilaian dengan menggunakan aplikasi penilaian untuk menjaga kemngkinan ada bukti fisik yang belum disiapkan.Hasil evaluasi ini juga dapat diketahui capaian sementara perolehan nilai yang adapat dikumpulkan oleh masing-masing kelompok standar, sehingga dapat dilakukan perbaikan.

\section{Dampak Hasil Inovasi}

\section{A. Hasil dan Dampak Inovasi}

\section{Hasil akreditasi}

Hasil yang dicapai dengan penggunaan metode sasambo ini terlihat data UPA KSB pada semua sekolah yang menjadi sasaran pembinaan di tabel 4.1 berikut:

Tabel 4.1. Perbandingan hasil akreditasi sebelum dan sesudah pembinaan dengan teknik SASAMBO

\begin{tabular}{cccc}
\hline \multirow{2}{*}{ No } & \multirow{2}{*}{ Nama Sekolah } & \multicolumn{2}{c}{ Peringkat Akreditasi } \\
\cline { 3 - 4 } & & Sebelum & Sesudah \\
\hline 1 & SDN Kertasari & B & A \\
\hline 2 & SDIT Binaul Ummah & $\begin{array}{c}\text { Tidak } \\
\text { Terakreditasi }\end{array}$ & A \\
\hline 3 & SDN 10 Taliwang & B & A \\
\hline 6 & SDIT Al-Fajra Sekongkang & $\begin{array}{c}\text { Tidak } \\
\text { Terakreditasi }\end{array}$ & B \\
\hline 7 & SDIT Harapan Bunda & $\begin{array}{c}\text { Tidak } \\
\text { Terakreditasi }\end{array}$ & B \\
\hline 8 & SDN2 Sekongkang & $\begin{array}{c}\text { A (84) } \\
\text { Tahun 2011 }\end{array}$ & $\begin{array}{c}\text { A (94) } \\
2018\end{array}$ \\
\hline
\end{tabular}

Dari data di atas memberi informasi positif bahwa pembinaan dengan menggunakan metode SASAMBO dapat meningkatkan akreditasi sekolah hingga mendapatkan nilai maksimal.Bahkan SDIT Binaul ummah yang baru pertama kali diakreditasi langsung mendapatkan nilai maksimal. SDN Kertasari, SDIT Binaul Ummah, dan SDN 10 Taliwang adalah hasil pembinaan tahun 2017 dengan penerapan metode sasambo yang sesuai dengan desain dan langkahlangkanh kegiatan. Sedangkan SDN 1 Taliwang dan SDN 4 Taliwang pembinaannya pada tahun 2012 tapi belum menggunakan istilah "Sasambo" karena saat itu penilaian akreditasi sekolah masih menggunakan 156 kreteria. Pembmbinaan kedua sekolah di atas menggunakan 156 Map dan hanya menggunakan kegiatan worksop selama dua hari.

Selain sekolah yang sudah menjadi sasaran penelitian di atas ada juga beberapa sekolah yang sudah dibina berdasarkan prinsip metode sasambo tetapi tidak optimal karena situasi dan kondisi yang tidak memungkinkan.Untuk sekolah-sekolah yang dimaksud hanya pembinaan berupa saran dan petujunjuk yang mengindikasikan pada 
prinsip sasambo, namun hasilnya cukup memuaskan hanya saja margin perolehan nilai tidak terlalu signifikan dan durasi waktu penilaian cukup lama.

\section{Efektifitas Metode Sasambo}

Efektifitas metode SASAMBO dapat dilihat pada tabel 4.2 berikut:

Tabel 4.2. skor rata-rata efektifitas metode SASAMBO meurut sekolah binaan

\begin{tabular}{lcccc}
\hline \multirow{2}{*}{ Sekolah } & \multicolumn{3}{c}{ Indikator Keefektifan } & Skor \\
\cline { 2 - 4 } & $\begin{array}{c}\text { Kinerja } \\
(\%)\end{array}$ & $\begin{array}{c}\text { Efesiensi } \\
\text { waktu (\%) }\end{array}$ & $\begin{array}{c}\text { Kemudah } \\
\text { an (\%) }\end{array}$ & $\begin{array}{c}\text { Final } \\
(\%)\end{array}$ \\
\hline SDN Kertasari & 85 & 90 & 90 & 88.3 \\
\hline SDIT Binaul Ummah & 85 & 85 & 85 & 85.0 \\
\hline SDN 10 Taliwang & 90 & 90 & 85 & 88.3 \\
\hline SDN 1 Taliwang & 85 & 85 & 85 & 85.0 \\
\hline SDN 4 Taliwang & 90 & 90 & 85 & 88.3 \\
\hline SDIT Al-Fajra Sekongkang & 90 & 90 & 90 & 90.0 \\
\hline SDIT Harapan Bunda & 85 & 85 & 85 & 85.0 \\
\hline SDN 2 Sekongkang & 90 & 85 & 85 & 86.6 \\
\hline Total rata-rata (\%) & $\mathbf{8 7 . 5}$ & $\mathbf{8 7 . 5}$ & $\mathbf{8 6 . 2 5}$ & $\mathbf{8 7 . 1}$ \\
\hline
\end{tabular}

Berdasarkan tabel 4.2 di atas, terlihat bagaimana respon guru-guru dan pihak sekolah terhadap keefektifan metode SASAMBO terhadap proses penilaian akreditasi sekolah. Pada angket respon terhadap efektifitas metode, penulis memfokuskan pada tiga hal utama yaitu kinerja, efisiensi, serta kemudahan. Masing masing dari ketiganya diuraikan menjadi 5 pertanyaan untuk mengetahui respon pengguna metode terhadap keefektifan proses persiapan penilaian akreditasi. Akhirnya diperoleh rata-rata respon sekolah terhadap efektifitas metode SASAMBO yaitu $87.1 \%$ dan berada pada kategori sangat efektif.

\section{Dampak/ Manfaat}

Pembinaan delapan standar dalam rangka peningkatan kesiapan sekolah untuk mengikuti penilaian akreditasi sekolah:

a. Manfaat bagi Sekolah

Manfaat yang didapat oleh sekolah, adalah sekolah memiliki dokumen administrasi yang tertata dengan rapi dan teratur berdasarkan indicator pada delapan standar.Keadaan tersebut memungkinkan sekolah untuk:

1) Mengetahui mutu sekolah.

2) Mempermudah mencari dokumen

3) Rapi dalam administrasi

4) Mempermuda dalam menyusun program

5) Memudahkan melayani tim asesor akreditasi sekolah. 
b. Manfaat bagi guru

Metode Sasambo yang dilakukan pengawas sekolah dengan melibatkan guru secara langsung memiliki fungsi pembinaan dalam rangka memahamkan delapan standar kepada guru sehingga guru dapat:

1) Memiliki standar yang jelas dalam membuat administrasi karena harus menyesuaikan dengan tagihan pada indickator delapan standar

2) Memiliki pengalaman manajmen administrasi sebagai bekal untuk memimpin jika suatu saat dipercaya menjadi kepala sekolah.

3) Menambah wawasan untuk mengembangkan kompetensinya serta lebih mudah memahami standar guru dalam pendidikan untuk menjadi lebih profesional

c. Manfaat bagi siswa

Metode SASAMBO yang diterapkan pada sekolah binaan memberikan peluang kepada siswa untuk mendapatkan pembelajaran yang lebih kreatif dan inovatif sebagai bagian dari tuntutan pemenuhan standar pendidikan yang harus dipenuhi dalam penilaian akreditasi.

\section{Simpulan}

Berdasarkan hasil dan pembahasan tentang penggunaan Metode Sasambo dapat dibuat beberapa simpulan atas efektifitas metode dalam pembinaan delapan standar pendidikan untuk menghadapi akreditasi sekolah yaitu sebagai berikut:

1. Metode SASAMBO merupakan metode yang mampu menertibkan administrasi sekolah dengan mudah, memudahkan kepala sekolah dalam mendelegasikan tugas administrasi kepada guru serta stapf kependidikan, mampu menciptakan suasana gotong royong dan kerja sama diantara warga sekolah, membantu sebagian besar guru dan staf kependidikan dalam memiliki pengalaman yang sama terhadap administrasi pendidikan yang berhubungan dengan 8 standar, dan mempermudah dan mempercepat tim penilai akreditasi sekolah dalam memperoleh data tentang kualitas sekolah secara otentik.

2. Metode SASAMBO efektif dalam membantu sekolah dalam meningkatkan kinerja, efisiensi waktu, serta kemudahan dalam persiapan menghadapi penilaian akreditasi sekolah.

\section{Saran}

Metode sasambo sebaiknya diterapkan pada semua sekolah baik yang akan mengikuti akreditasi sekolah maupun yang belum mendapat giliran diakreditasi. Metode Sasambo dapat menertibkan admintrasi sekolah karena data sekolah terkontrol dengan rapi pada map penyimpanan 


\section{Daftar Rujukan}

Adnan Muhammad, 2017, Laporan Hasil Visitasi Akreditasi Sekolah Dasar di Kabupaten Sumbawa Barat: Taliwang, UPA KSB

Depdiknas.2003 “Undang-undangSistemPendidikanNasionalNomor 20 Tahun 2003" Jakarta. Depdiknas

Depdiknas, 2010 :Permendiknas Nomor 15 tahun 2010 tentang Standar Pelayanan Minimal Pendidikan Dasar: Jakatra. Depdiknas

Kasman, Dr.M.Pd, 2015 :Materi Pelatihan Integrasi SPM dalam RKAS: Jakarta. Kemendikbud

Kemendikbud 2017, Permendikbud Nomor 002/H/AK/ 2017 tentang Revisi Prangkat Akreditasi Sekolah , Jakatra Depdikbud

Lawang Robert MZ, 2014: Artikel Kajian Sosialisasi dalam Masyarakat Mutietnik: Jakarta, Gramedia 
Jurnal Lentera

Jurnal Studi Pendidikan

20|Edisi 1 No 2 Juli 2019 